\title{
Creating wildlands in Costa Rica: Historical ecology of the creation of Corcovado National Park
}

\author{
Christopher Vaughan ${ }^{1,2,3}$ \\ 'Dept. of Wildlife Ecology, University of Wisconsin, Madison, WI 53706; cvaughan@wisc.edu \\ ${ }^{2}$ International Institute in Wildlife Conservation and Management, Universidad Nacional, Heredia, Costa Rica \\ ${ }^{3}$ Associated Colleges of the Midwest, San Jose, Costa Rica; cvaughan@acm.edu
}

Received 20-II-2012 Corrected 30-III-2012 Aceptado 19-IV-2012

\begin{abstract}
Half of present wild land areas are found in tropical countries and were created after 1970. However, human activities have been seriously altering protected tropical wild lands and $75 \%$ of Latin American wild lands lacked effective protection, long-term management plans and economic resources to guarantee effective management. Partial blame for this is directed at how protected areas were conceived and implemented, using the U.S. preservationist model of setting aside undisturbed habitats "for the enjoyment of current and future generations" and not accounting for local people's histories, interests or rights. The objective of this paper is to trace the historical ecology of the creation of Corcovado National Park in the Peninsula of Osa, Costa Rica. This article presents a historical reconstruction of how an area was created, actors involved and their interactions to provide insights to current outcomes of national conservation planning and management. The park is one of the most diverse ecological systems for its size on earth, but is exposed to settlement, lumber interests, hunting and goldmining. Open communication and searching for win-win situations fomented the creation of Corcovado National Park and may hold the key for its sustainability.
\end{abstract}

\section{KEY WORDS}

Conservation, history, Costa Rican park system, Tropical conservation, Osa Peninsula.

\section{RESUMEN}

La mitad de las áreas silvestres actuales, se encuentran en los países tropicales y se crearon después de 1970. Sin embargo, las actividades humanas han alterado gravemente las áreas silvestres protegidas tropicales y el $75 \%$ de las áreas silvestres de América Latina carece de protección efectiva, planes largo plazo y recursos económicos para garantizar una gestión eficaz. Una causa parcial es que las áreas protegidas fueron concebidas utilizando el modelo conservacionista de EE.UU. de apartar hábitats no alterados "para el disfrute de las generaciones actuales y futuras", sin tomar en cuenta la población local. El objetivo de este trabajo es documentar la ecología histórica de la creación del Parque Nacional Corcovado en la Península de Osa, Costa Rica. Este artículo presenta una reconstrucción histórica de cómo se creó el área, los actores involucrados y sus interacciones, en busca de una mejro planificación nacional de conservación. Considerando su tamaño, el parque es uno de los sistemas ecológicos más diversos del mundo, pero está expuesto a problemas relacionados con la extracción de madara, fauna y oro. La comunicación abierta y la búsqueda de situaciones beneficiosas para todos fomentó la creación del Parque Nacional Corcovado, y puede ser la clave para su sostenibilidad.

PALABRAS CLAVE

Conservación, historia, Costa Rica, sistema de parques, conservación tropical, Península de Osa.
In 1989, there were over 4500 public national parks and equivalent reserves covering over 4.8 million $\mathrm{km}^{2}$ worldwide (Reid \& Miller 1989). By 1999, 12 million km² of protected areas covered $8 \%$ of the Earth's land surface (Worldwatch Institute 1999). About half of present wild land areas are found in tropical countries; most were created after 1970. However human activities have been seriously altering protected wild lands in tropical countries.
Over 75\% Latin American wild lands lacked effective protection, long-term management plans and economic resources to guarantee effective management (World Conservation Monitoring Center 1992). What had generated these problems?

Partial blame was directed at how protected areas were conceived and implemented. Most tropical countries 
followed the U.S. preservationist model for national park creation by setting aside undisturbed habitats "for the enjoyment of current and future generations" (Hales 1989). When a national park was created, government officials attempted to stop local community traditional natural resource use inside (Kramer \& VanSchaik 1997). This generated conflicts between park officials and local inhabitants. Resentful (and usually impoverished) local residents continued to "illegally" exploit natural resources inside the parks. Traditional enforcement (fines, fences and patrolling) was ineffective and authorities backed by international support, sought new approaches to protect national parks and equivalent reserves (Brandon \& Wells 1992).

In the 1970s, UNESCO's Man and the Biosphere Program introduced the idea of Integrated Conservation-Development Projects (ICDPS), linking protected areas conservation with local community development (Batisse 1986). The World Conservation Strategy stated that protected areas conservation had to be linked with local community economic activities (International Union for Conservation of Nature and Natural Resources 1980). Delegates at the IUCN World Congress on National Parks in Bali in 1982 reiterated this statement, stressing that ICDPS be promoted with national parks and protected areas (McNeely \& Miller 1984). In 1990, The World Bank, UNDP and UNEP jointly created the Global Environment Facility (GEF) to facilitate and fund projects integrating environmental issues into development projects. One of GEF's four focal areas was to protect biodiversity and promote local development through ICDPS (Ledec \& Goodland 1988).

However, after two decades, hundreds of ICDPS, and billions of GEF, USAID, NORAD and other donor dollars, wild lands destruction is escalating (Terborgh 1999, Wilson 1989, Whitmore \& Sayer 1992). Scientists are now engaged in critically analyzing ICDPS and wild lands-human relations and proposing new guidelines (Brandon et al. 1998, Brandon \& Wells 1992, Rao \& Geisler 1990, Redford et al. 1998, VanSchaik et al. 1997, Wells 1994, Wells \& Brandon 1992). Wells (1994) summarizes these guidelines as: a) involving local people, b) developing social, economic and eclogical criteria for each site, c) carrying out projects in the spirit of applied research and adaptive learning, d) mobilizing a wide array of human and organizational resources, and e) developing new quantitative and qualitative techniques and indices for monitoring and evaluation. However, the evidence indicates that many of these ideas will be difficult to implement in the short-term. Where have we gone wrong?

We should start with the creation of a wild land area or system. The reconstruction of those events, actors involved and their interactions may provide insights to current outcomes of national conservation planning and management. Sellars (1997) mention numerous historic individual national parks creation accounts for the United States National Parks. In developing countries, Boza \& Bonilla (1981) wrote general accounts of the Costa Rican wild lands system. Gandoca-Manzanillo National Wildlife Refuge is only Costa Rican wild land which has a detailed history of its creation, told from the eyes of a writer (Rossi, 1993). Authors in Brandon et al. (1998) trace establishment of nine national parks in Latin America as part of a reconstruction of their successes and failures, but were limited in many cases as short-term consultants. And normally individuals directly involved in wild lands creation don't have time or skills to document protected wild lands creation or explain linkages between stakeholders. The objective of this paper is to trace the historical ecology of the creation of Corcovado National Park in the Peninsula of Osa, Costa Rica.

\section{METHODOLOGY}

While employed (1971-1975) as a biologist and planner with the Costa Rican National Parks Department (CRNPD) and the Tropical Science Center (TSC), my colleagues and I laid the framework for creation and then consolidation several national parks and equivalent reserves in Costa Rica. One of them was Corcovado National Park (CNP), a 34346 hectare wild land area created in 1975 (Vaughan 1981). The methodology used to gather information for this CNP's creation, Vaughan (1981), and this paper included: (a) literature review, (b) biotic surveys, (c) informal conversations with and observation of stakeholders, and (d) data gathered by informants.

\section{RESULTS}

\section{Outline of Article}

This paper presents a historical perspective and reconstruction of the creation of CNP, Osa Peninsula, Costa Rica. It focuses principally on the park, but draws from other areas of the Peninsula and Costa Rica as needed. Major stakeholders and their interactions determined the chain of events culminating in creation of CNP in October of 1975 (Table 1)(Vaughan 1981, Vaughan \& Rodriguez 1997). Other historians have looked at the theme of sustainability and development on the OP (Christen 1994, Cuello 1997), but have not detailed creation of CNP. The sequence of this paper is the following:

a. The Osa Peninsula in 1974

b. Stakeholders in the Creation of Corcovado National Park 
TABLE 1

Interaction of Stakeholder A on Stakeholder B

\begin{tabular}{|c|c|c|c|c|c|c|c|c|c|}
\hline$A \backslash B$ & Settlers & $\begin{array}{l}\text { Osa Forest } \\
\text { Products }\end{array}$ & $\begin{array}{l}\text { Foreign } \\
\text { Scientists }\end{array}$ & Donors & $\begin{array}{l}\text { Costa } \\
\text { Rican } \\
\text { Congress }\end{array}$ & $\begin{array}{l}\text { President } \\
\text { Oduber }\end{array}$ & $\begin{array}{c}\text { CR } \\
\text { National } \\
\text { Parks } \\
\text { Dept }\end{array}$ & $\begin{array}{c}\text { Corcovado } \\
\text { National } \\
\text { Park }\end{array}$ & Totals \\
\hline Settlers & &,-- &,- 0 &,- 0 &,+ 0 &,- 0 &,-- &,-- & $\begin{array}{l}\text { BC- } 6,+1 \\
\text { AC-3,04 }\end{array}$ \\
\hline $\begin{array}{l}\text { Osa Forest } \\
\text { Products }\end{array}$ &,-- & & $+/-, 0$ & 0,0 &,- 0 &,-+ &,-- &,$--/+$ & $\begin{array}{l}\text { BC- } 5,+/-1 \\
\text { AC- } 1,01 /\end{array}$ \\
\hline $\begin{array}{l}\text { Foreign } \\
\text { Scientists }\end{array}$ & $-/ 0,0$ &,- 0 & &,++ &,++ &,-+ &,++ &,++ & $\begin{array}{l}\mathrm{BC}-3,+4 \\
\mathrm{AC}+5, \mathrm{O} 2\end{array}$ \\
\hline Donors & $0,+/-$ &,$- \mathrm{O} /-$ &,++ & & $0,+$ &,++ &,++ &,++ & $\begin{array}{c}\mathrm{BC}-1,+4, \mathrm{O} 2 \\
\mathrm{AC}+5,+/-1, \mathrm{O} /-1\end{array}$ \\
\hline $\begin{array}{l}\text { Costa Rican } \\
\text { Congress }\end{array}$ &,-+ &,-- &,++ &,++ & &,-+ & $+/ o,+$ & $+/ 0,+$ & $\begin{array}{c}\mathrm{BC}-3,+3,+/ \mathrm{O} 1 \\
\mathrm{AC}-1,+6\end{array}$ \\
\hline $\begin{array}{l}\text { President } \\
\text { Oduber }\end{array}$ &,-+ &,++ & $+/ 0,+$ & $+/ 0,+$ &,-+ & & $+/ o,+$ & $+/ 0,+$ & $\begin{array}{c}\mathrm{BC}-2,+1,+/ \mathrm{o} 4 \\
\mathrm{AC}+7\end{array}$ \\
\hline $\begin{array}{l}\text { CR National } \\
\text { Parks Dept }\end{array}$ &,$--/+$ &,- &,++ &,++ &,++ &,++ & &,++ & $\begin{array}{c}\mathrm{BC}-2,+5 \\
\mathrm{AC}-1,+5,--1+1\end{array}$ \\
\hline $\begin{array}{l}\text { Corcovado } \\
\text { National Park }\end{array}$ & $0,-1+$ &,-+ &,++ &,++ & $+/ 0,-/+$ & $+/ 0,+$ &,++ & & $\begin{array}{c}\mathrm{BC}-1,+3,01,+102 \\
\mathrm{AC}+5,-/+2\end{array}$ \\
\hline
\end{tabular}

c. The Tip of the Iceberg with OFP precipitates creation of Corcovado National Park

d. Aftermath and Lessons Learned

e. An Analysis of Stakeholder Interactions.

\section{The Osa Peninsula in 1974}

\section{General human related activities}

In 1974, the Osa Peninsula (OP) represented one of Costa Rica's last frontiers. Its 160 000ha were the largest remaining lowland rainforest on the Pacific coast of Central America (Fig. 1). The OP was linked to the mainland by a $15 \mathrm{~km}$ wide road less corridor, most of which was impenetrable mangrove forest. Although biotic exchanges were facilitated with the mainland, no roads connected the OP to the outside world. An estimated $80 \%$ of its forests were intact in 1974, owing to the inaccessibility of the OP, its low human population and the fact that $40 \%$ was owned by an inactive transnational lumber company (Vaughan \& Rodriguez 1997).

This pattern of development changed dramatically from 1972 to 1974 when total OP population doubled. Construction of the Interamerican Highway South promoted migration to the OP (Cuello et al. 1998). Immigrants moved into the OP from towns in southern Costa Rica, such as Sierpe, San Isidro del General, Parrita and areas of the OP as well as from Panama, Nicaragua, Honduras and the United States. The OP had become a popular colonization site for farmers, land-speculators and gold miners. About 85\% of the 6177 OP citizens in 1974 lived on the eastern or Golfo Dulce side, which was more accessible and had some amenities (health clinic, bank, roads, schools) then the isolated Pacific side. However, the western or Pacific side, future site of CNP, experienced almost a quadrupling of population (70 to 247 individuals) (Fig. 2) (Costa Rica, Ministerio de Salud 1975). Most OP families were dedicated to agriculture. The Golfo Dulce side of the 


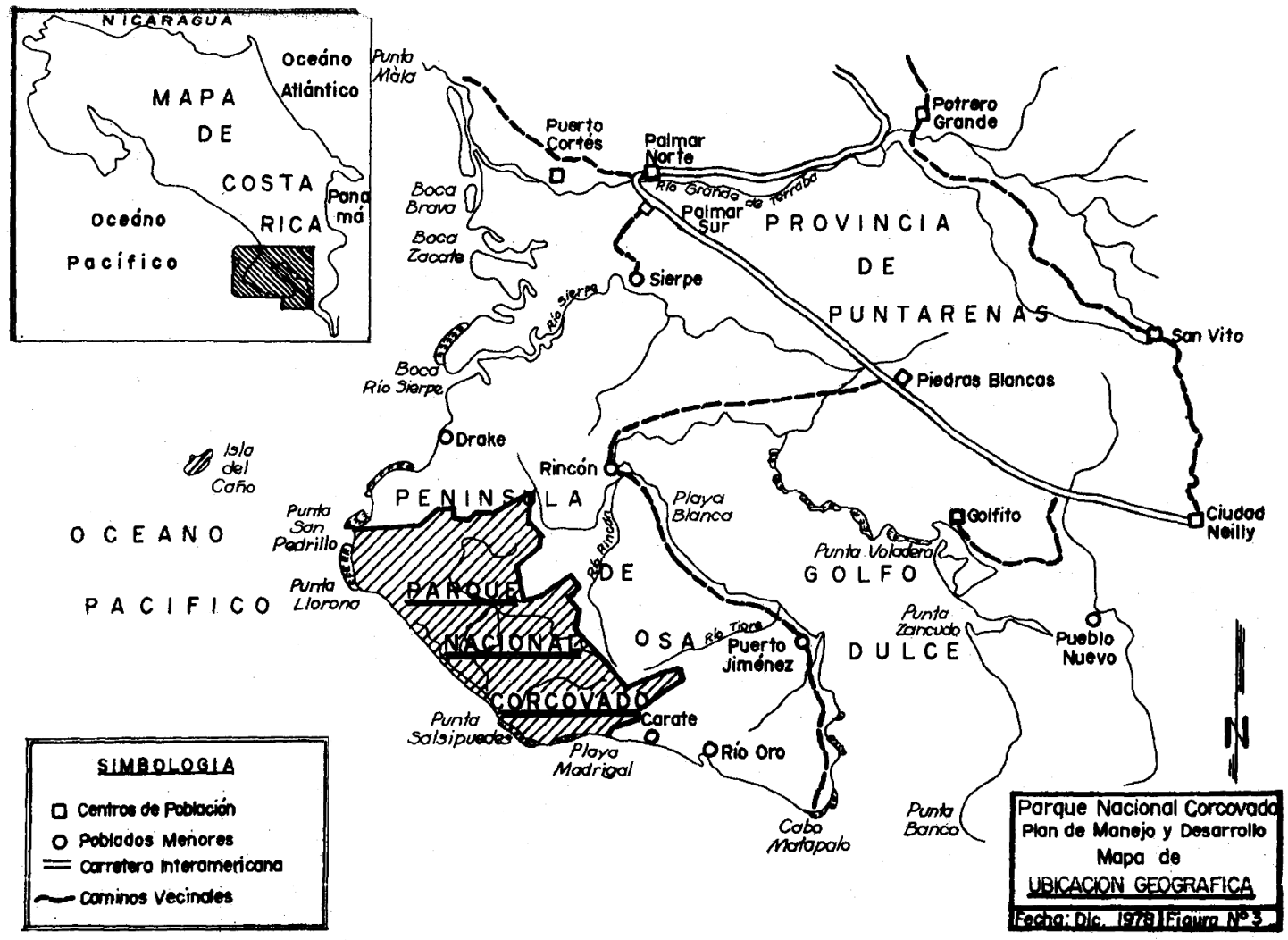

FIG. 1. The Osa Peninsula showing the location of Corcovado National Park (Vaughan 1981).

OP was more developed with an estimated 14 500ha cultivated. Over 9700 ha or $67 \%$ was in pastures and grazing over 10668 head of cattle in 1972. The rest of the cultivated land was dedicated to annual (corn, rice and beans) and perennial (plantains, bananas, fruit trees) crops (Costa Rica. Direccion General de Estadisticas y Censos 1973).

In 1975, the OP still had a tremendous amount of commercial woods remaining. Little commercial logging had occurred there because: a) access was limited, b) commercial demand for wood was limited to local use, c) harsh climatic and topographical conditions made lumber exploitation difficult, and d) OFP controlled, at least in theory, most of the forested land. Those forested areas not under OFP control were public lands of difficult access in the center of the OP. Only two small sawmills were operating on the east side of the Osa Peninsula in 1974. There was an incredible variety of tree species in the $\mathrm{CB}$ and many were commercially attractive.

Travel to and within the OP was difficult and time-consuming. Most OP inhabitants traveled from the mainland to the OP by boat, crossing the Golfo Dulce from the United Fruit banana town of Golfito to Puerto Jimenez, capital of the OP. A few flew from Golfito or San Jose to Puerto Jimenez. Motorized vehicle transportation within the OP was on an unimproved dirt road that connected the eastern coast from Rincon to Puerto Jimenez, the capital town with 600 inhabitants in 1974.

\section{Biological diversity}

Of the $80 \%$ of the OP which was still forested in 1974 , the most intact ecosystems were in the central highlands and the Corcovado Basin (CB), found on the west coast. Larry Gilbert, University of Texas scientist, stated that "The diversity of ecological systems found on the Osa is not exceeded by any area of comparable size on earth". He was referring to the $C B$ and surrounding watershed. It is the heart of biological diversity for the OP and arguably for Costa Rica. Found in one of the wettest and most remote areas in Central America, differences in topography, altitude, microclimate, soils, drainages and other factors have 


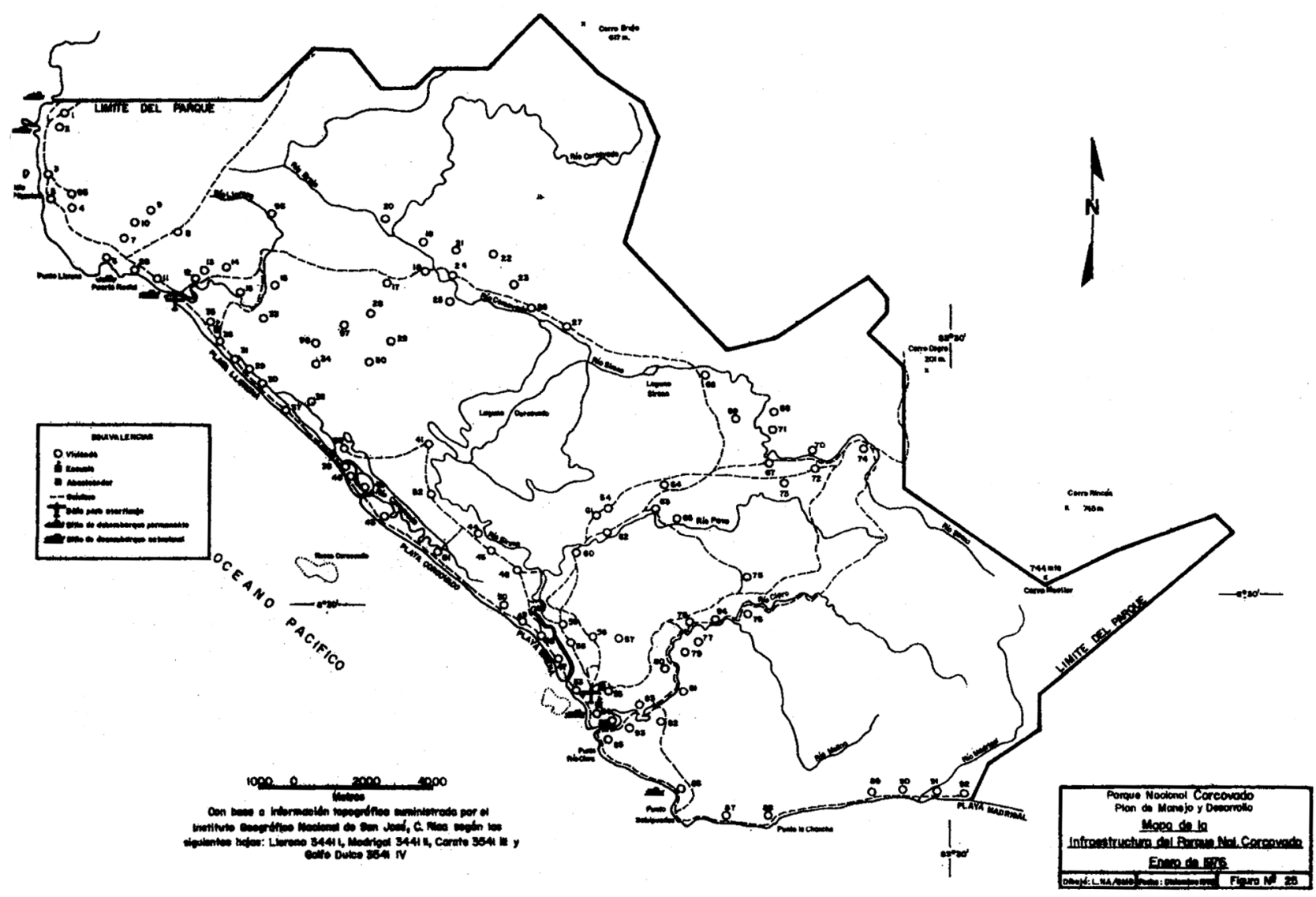

FIG. 2. The Corcovado Basin in 1974 with farms and trails (Vaughan 1981).

shaped a unique complexity of vegetation in a relatively reduced area $\left(450 \mathrm{~km}^{2}\right)$ (Hartshorn 1984, Vaughan 1981). The $C B$, covering about 14000 ha, was originally part of an inland sea which became partially silted and cut off from the Pacific Ocean over time. Fully $25 \%$ of the tree species found in Costa Rica inhabit the CB and surrounding areas. This includes over 1513 identified tree species of an estimated 3000 (Soto 1992). My botanist colleagues and I can testify that some of the largest trees in Central America's tropical forests, towering over $60 \mathrm{~m}$ high, are found in the CB. The wildlife is equally rich; over 375 bird species (including 18 endemics), 124 mammal species, 46 amphibian species, 71 reptile species, 61 freshwater fish species, and an estimated 8000 insect species have been reported (Soto 1992, Vaughan 1981).

\section{Early anthropomorphic influences and the United Fruit Company in the $C B$}

The Osa Peninsula is one of three archeological subregions of the Southern Pacific Region of Costa Rica. Their pottery is related to that of the Borucas of the General Valley (Costa Rica) and the Chiriqui area (Panama) where they probably came from. The first indigenous groups to arrive were hunters, fishermen and gatherers, but also had well-developed agricultural knowledge, planting corn. It is thought they were attracted to the $C B$ because of its abundant wildlife, fishing and localized fertile soils. Some archeologists consider the Corcovado region important because it is geographically situated between other archeological subregions and is close to Cano Island, the major cemetery for indigenous groups in the region. Local settlers showed me several burial grounds, usually found on hillsides and pottery picked up while clearing land for farming.

By the 1930s, the Costa Rican Banana Company, a subsidiary of United Fruit Company, was exploiting hardwoods and exploring the Pacific lowlands of Central America for precious woods and to increase their plantings of banana and oil palm, which already dominating fertile, lowland landscapes close to the OP (Tucker 1990). 
I saw cement bases of the houses built by the Costa Rican Banana Company in 1943 on Corcovado beach. Technicians sent to the $C B$ to study the feasibility of establishing banana or African oil palm plantations had lived there. After several months of exploration which included soil sampling, humidity and profile gradients, their final report emphasized the negative conditions for massive banana cultivation because of irregular topographical conditions and a mosaic of alluvial, regasoils and hydromorphic soil types scattered throughout the Corcovado lowlands. They concluded that banana cultivation would require vast systems of irrigation and drainage in the dry and wet seasons respectively. For these reasons, the technicians concluded that banana production would be profitable for only five years in the Corcovado lowlands and alternative sites presented better options (soils, topographic, accessibility) (Compania Bananera de Costa Rica 1945). After viewing the cement bases and report, it was gratifying to know that the $C B$ had been saved from the multinational banana companies, although settlers, gold miners, and another multinational would impact it.

\section{Stakeholders in the creation of Corcovado National Park}

In the early 1970 's, seven major stakeholders: a) subsistence farmers and goldminers, b) a transnational development company, c) international conservation donors, d) foreign scientists, e) the Costa Rican Congress, f) the President of Costa Rica, and g) the CRNPD wrestled over control of the CB (Cuello et al. 1998). The first two groups would have converted $C B$ and surrounding lands to agriculture or other development in several years time, destroying its biological diversity. The foreign scientists and international conservation donors worked for the creation of CNP. The Costa Rican Congress was initially more interested in expropriating lands from the transnational development company, while President Oduber attempted by all means to stop the expropriation of its in holdings. Eventually both Congress and Oduber got together and created CNP as part of a package involving OFP. The CRNPD had a clear agenda to mediate, control and manage CNP, which they obtained. Stakeholders involvement and interaction, shifts in direction, positioning and sudden turns of events in the creation of CNP present an interesting case study which I construct below (Vaughan \& Rodriguez 1997)(Table 1).

\section{Subsistence farmers and goldminers-Subsistence agriculture}

Like the indigenous peoples, earlier settlers in the $C B$ were attracted by the abundant wildlife, fishing and fertile soils for agricultural development. Physical isolation of the $C B$ from the rest of the OP and the fact they were "squatters" on OFP land ensured limited contact between CB settlers and OFP. Understanding their origins, family structure, life style and interactions with nature are an important part of CNP history. Their relation with nature included: (a) lands deforested for agriculture and livestock use, (b) impacts on certain wildlife species caused by hunting, and (c) exploitation of certain valuable forestry trees.

Most CB inhabitants lived a subsistence economy. They cultivated almost all the agricultural products they ate, which included rice, beans, corn, bananas, plantains and fruit from lime, orange, guanabana, and avocado trees. One of the principal economic activities of the local inhabitants was the maintenance of domestic pigs, cattle and chickens. Many complemented their protein diet with hunting wild animals, eating sea turtle eggs, and occasionally fresh or salt water fish and seafood (crabs, mollusks, etc.). Some locals ate fruit or leaves of native tree species. Trading was common among the residents. Other consumption goods were brought from the only general store in Sirena, owned by Felix Avellan or outside the CB. There was no health center nor doctors, two schools existed in 1974 , along with one electric generator and no taxation.

Up to the creation of CNP, about 1800 ha or $5 \%$ of CNPs land surface, had been deforested. In many areas, these lands were not under cultivation, but were being speculated on. Men would deforest between 2-15ha and claim an adjoining 150-300ha. This land could be bought and resold up to 4-5 times a year. At the other extreme were residents such as Francisco Marenco who had farmed his 200 ha for over 20 years. Most of these farms, which varied between 15 and 150 ha were found on the fertile, elevated, alluvial soils between the Claro and Pavo rivers.

These agricultural products provided food for an almost self-sufficient life style in the CB. Before 1975, almost nothing was marketed outside the $C B$ because production was low and internal demand high. Seventy-seven of 99 families were recent immigrants (less then three years) planning to harvest for the first time in 1976 (Fig. 2). As a result, the recent settlers created a demand for food which long-term residents hastened to supply. Lack of roads and high costs for air or sea transportation accentuated the situation. Still, plantains were sometimes shipped to Puntarenas through San Pedrillo. Marijuana was grown and shipped out. Once CNP was created and the settlers prepared to leave, they sold the National Council of Production 21400 pounds of rice, 1800 pounds of corn, 28 bags of jaragua grass, and 9200 pounds of beans (Vaughan 1981) and it was exported by government planes. This purchase of the Corcovado families' yearly food supply was probably a government tactic to rid them of a food supply, thus ensuring their exodus from the park. 
In 1974, there was no agricultural mechanization in the Corcovado region. Corn, rice and beans were planted in primitive ways, using a stick or hand-casting. Slash and burn agriculture was still common. Farmers used no chemical fertilizers or pesticides and only employed herbicides in some deforested areas. Cattle and swine were sprayed against skin diseases. There were still many unoccupied lands. Most agriculture was concentrated in the alluvial, well-drained soils, unquestionably the best for farming. Observations confirmed that $100 \%$ of $C B$ lands were claimed by settlers. In a year or two, the 1800 ha deforested would probably have tripled or quadrupled. One investor planned to deforest 400ha of swamp land in 1976-1977 and plant rice in large scale with heavy machinery.

But travel to the Pacific coast of the OP was dangerous and very difficult. This limited excursions and goods transported to the minimum. To reach the northern part of the Pacific side of the OP (Drake), some traveled by boat down the Sierpe river. Others used the biweekly launch, weather permitting from Puntarenas, $100 \mathrm{~km}$ to the north (Vaughan 1981). However, over $90 \%$ of the inhabitants walked on trails through the mountains from the Golfo Dulce side of the OP west or vice versa. An alternate route was along the southern beach route from Carate to Sirena (Fig. 2). Occasionally boats or planes would be hired to travel from Golfito or Sierpe to Sirena, where there was one unimproved airstrip. Only two or three beaches on the Pacific side were considered safe for docking.

\section{Swine}

Domestic pigs were common in Corcovado and most year-round farmers had between 10-80 pigs. My colleagues and I estimated over 600 domestic pigs in the $C B$ during 1976 (Vaughan 1981). These pigs ran freely feeding on coconuts, garbage, crabs and turtles eggs on the beach and seeds, fruit, leaves, roots and small animals (lizards, snakes, bird eggs or chicks) in the forest. Apparently, they occasionally joined herds of white-lipped peccaries (Tayassu pecari). On many occasions, we witnessed the pigs and the extent of their uprootings on the beach and in the forest. Their impact on seed dispersion (they grind up most seeds), populations of organisms and turtle eggs must have been great. Pigs were probably preyed on by jaguars and mountain lions. The pig farmers had a relatively easy crop to manage, although they receive only about US\$50 for an 18-month old pig. Pigs were rounded up and walked to San Pedrillo, the Claro river or Salsipuedes, where they boarded boats to outside markets.

\section{Cattle}

Beginning in the 1960s, there was increasing pressure on the forested regions of the $C B$ to convert them to pasture. The same pattern occurred on the east side of the OP, which had two-thirds of its deforested landscape with over 10668 head of cattle by 1973 (Costa Rica, Direccion Nacional de Estadistica y Censos 1973). In the CB, an estimated $90 \%$ of the 1800 ha deforested were in pastures. Many residents planned to make medium sized cattle ranches because it required less labor then traditional crops and bank loans for cattle were easily obtained because of international beef prices. Total population of $C B$ cattle was about 500 head when CNP was created, and Franciso Marenco owned $40 \%$ of them. Most people considered cattle to be as profitable as swine because they reproduced and grew quickly and could walk to market. Residents were beginning to deforest marginal areas in steep hillsides around Sirena and cattle expansion definitely threatened CNP creation.

Most cattlemen in CB used the "African Star" pasture grass, because it had the following advantages: (a) grew where other agricultural crops couldn't, (b) planted extensively without requiring mechanization, and (c) covered areas semi permanently without permitting other plant colonization. By 1974, African star grass was the dominant pasture cover, adapting to both the steep hillsides on Claro river and the lowland areas.

As mentioned, international beef markets made bank loans easy to acquire. In January, 1976, an agricultural inspector from a Costa Rican bank stated that CNP residents had 12 outstanding loans for about US\$25 000 with $88 \%$ for purchasing cattle or planting pastures (Costa Rica, Banco Anglo Costarricense 1976)

\section{Lumber exploitation}

In the $C B$, there were signs of exploitation of valuable timber species close to the Pacific Ocean, probably by the Costa Rican Banana Company between 1930-1950. Demand for lumber in the CB was limited to local uses and only two portable sawmills operated there making rough boards and other cuts for constructions and fencing. Furniture had to be elaborated by hand with crude instruments. Almost half of the families in Corcovado owned a chainsaw, several had three, and one man had 11. These chainsaws were used primarily to clear the forest for planting pasture or land speculation. Some residents worked full-time clearing forests for settlers in the area. The most utilized trees in the CB were: Hieronyma tectissima (pilon), Virola koschnyi (fruto dorado), Cedrela mexicana (cedro), Calophyllum brasiliensis (maria), and Brosimum costaricanum (ojoche). In addition, several tree species were left 
standing because of medicinal value. These included: Trichilia propinqua (canfin) whose bark was placed inside rubber boots to avoid athletes foot or to light fires. Other species used were Trattimickia aspera (carrano) to cure infections and Simaruba cedron (cedron) for fevers.

\section{Commercial and subsistence hunting}

Before CNP was declared, most families hunted on a weekly basis. Most families had a .22 caliber rifle and about 50\% had hunting dogs (Vaughan 1981). We saw and heard many hunting dogs throughout the $\mathrm{CB}$. Hunting parties came from settlements adjacent to the Park, such as La Palma, Pt. Jimenez and Carate. They took meat back to their villages for personal use or to commercialize. Skins or pelts from felid species, otters, and peccaries were collected and sold bimonthly to a trader who walked through the CB region (Vaughan 1974). Professional crocodilian hunters had hunted caiman and crocodiles around the Corcovado between 1944-69, harpooning, skinning and selling their hides in Puntarenas for exportation to Japan. Their business disappeared in the late 1960s when plastics imitating animal skins destroyed the hide market.

By 1974, most commercial hunters had disappeared because of declining game populations and competition with CB family hunters. Pacas, brocket deer, spider monkey and several species of game birds (guans, chachalaca and tinamus) were pursued. However, hunting intensified around the Corcovado Lake region in the dry season when tapir, white-lipped peccary and collared peccary congregated with receding water levels. These species were rarely observed when we first began entering the park.

\section{Goldminers}

Goldmining in the OP has been highly publicized. It was begun in 1937 on the Tigre river (Golfo Dulce side) and attracted many gold panners from throughout Costa Rica. Working its way towards the southeast as they exhausted the gold, the goldminers reached the Madrigal River, limit to present day CNP, in 1939. After discovering gold in the sand on the beach there, a "gold rush" began, complete with a movie theater, general store, brothel and bar. This was short-lived.

When CNP was created, there were about 300 active goldminers on the OP and 15 in CNP. In CNP, they spent most of their time panning for gold in the Claro river watershed. Most had no property, but traveled between claims, building temporary shacks along the rivers and streams. Their earnings averaged about US\$15 a month. Few struck it rich, but many were caught with gold fever. Most goldminers in the $\mathrm{CB}$ traveled to the general store at Sirena on a monthly basis to sell their gold and pick up supplies and liquor. I noted that miners put bags of rice and beans, candles, matches, and several bottles of liquor into gunny sacks. Rafael Rubi, a goldminer, told me that they lived up to two years at the same site. The panning technique was very crude and most goldminers gathered gravel from the stream and "washed" it in a large pan until the lighter gravel and sand dropped out and the heavier gold sank to the bottom. Its bright metallic color gave it away. Another method used was to erode/dig away part of a hillside with a shovel or hose connected ingeniously to a water source. When the dirt and gravel was washed into a stream or river, the goldminer panned the gold just as in the earlier situation. There had been commercial operations with heavy machinery, but they were concentrated on the Madrigal river. The few goldminers in CNP didn't impact the environment with their primitive methods. However, ten years later when the numbers swelled to over 600 , things got very complicated (Naughton 1993, Cuello 1997)

\section{Transnational Development Company}

Osa Forest Products (OFP) was the second major stakeholder involved in the history of CNP. OFP was legally registered in Costa Rica in 1959 and given permission for forestry and mining concession in its holdings, which totaled 61 660ha up to October of 1975 (Fig. 3) (Vaughan 1981). OFP critics considered them transnationals speculating on land for tax write off purposes in the United States. Their lands were valued in the Costa Rican Property Tax Division at US\$200 000 and they paid only US\$1 000 a year in property taxes (Costa Rica, Asamblea Legislativa 1973). OFP originally planned to operate a sustainable forestry operation with rotational harvesting and reducing wood byproducts to maximize returns. However, except for rice planting and limited logging in about $10 \%$ of their land, its lack of a clear land use policy precipitated a flood of settlers from Costa Rica, Panama and Nicaragua and serious land disputes (Vaughan 1981). Some "squatters" on OPF land had resided there for over 40 years before OFP arrived in 1959. Few had requested legal rights to their farms. When OFP became legal owners, they attempted to control the situation by asking all "squatters" to inscribe their farms with the Costa Rican Institute for Lands and Colonization. In other cases, occupants were asked to sign a "rental contract " with OFP for US\$0.12 a year. Most didn't comply with either the inscription or the rental contract. But OFP wanted to control land tenure on their properties because by 1973 , there were 1160 farmers occupying about 10162 ha, or $21 \%$ of OFP lands) (Costa Rica. Instituto de Tierras y Colonizacion 1975a, 1975b, 1976). This period in Costa Rican and regional history was also marked by a 


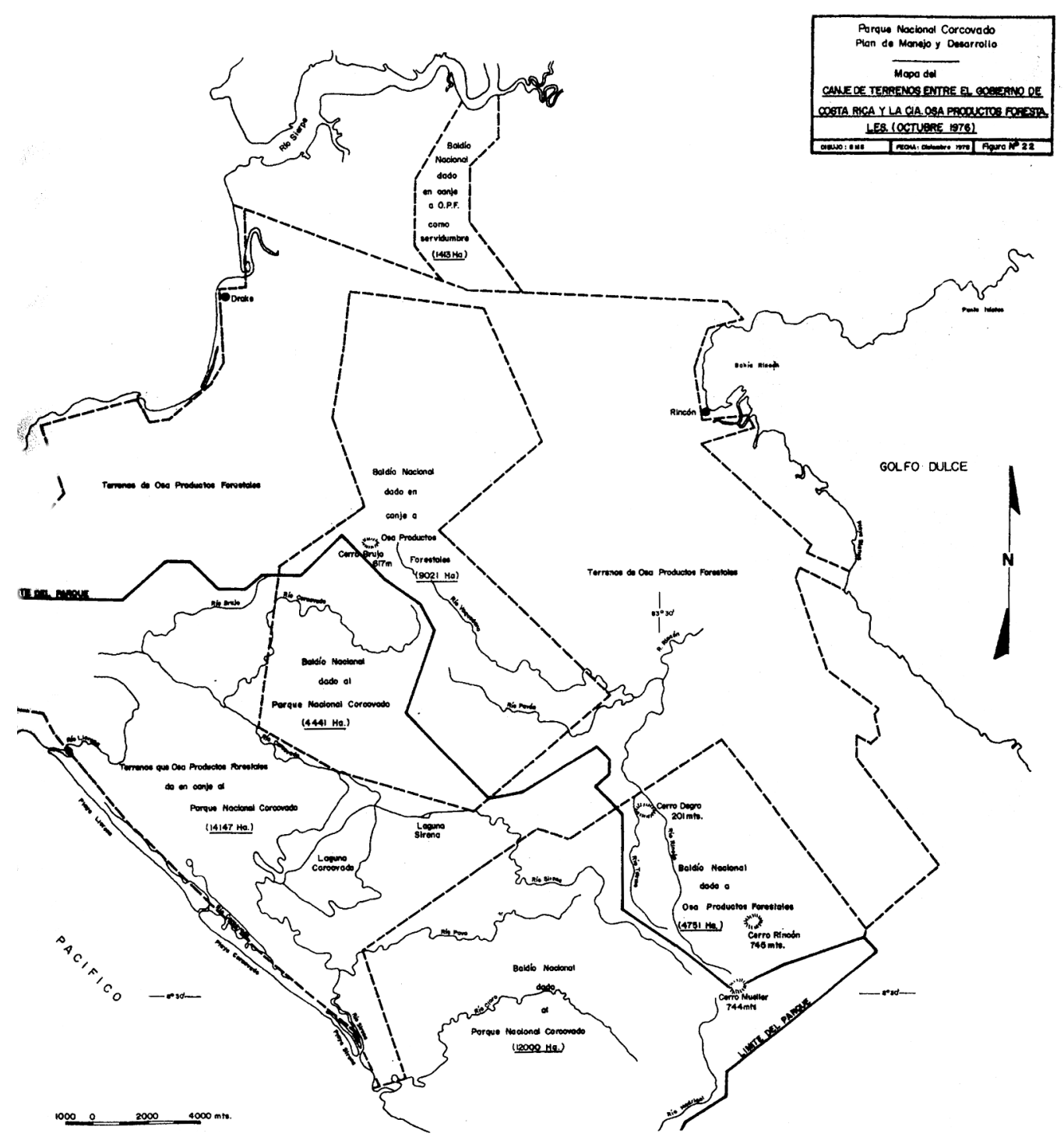

FIG. 3. The land exchange between Osa Productos Forestales and the Costa Rican government which created Corcovado National Park (Vaughan 1981).

proliferation of anti-imperialist activity from the Costa $\mathrm{Ri}$ can Socialist Party to which many of OFP "squatters" obviously belonged.

Between 1971-1973, charges of tax evasion, landhoarding, repressive actions against settlers, corruption and other activities were leveled against OFP by congressmen from Costa Rica's national legislature (Christen 1994, Vaughan 1981). OFP quickly became an example of "land-hoarding" leveled at foreigners and their companies who neither used land, nor permitted nationals to use it. But, OFP seemed oblivious to the growing storm of internal and external discontent with their policies. Between 1971-1972, OFPs manager began massive road construction to force evictions in its holdings. Armed squatters captured OFP staff and a tractor in the CB and warned that if OFP persisted in its attempts to evict settlers on their land, "blood would flow". OFP asked the Rural Guard to come to its rescue (Christen 1994), but they were scared. In my first visit to $C B$, after walking for two days on the 
bulldozed road OFP had made, it ended near the beach where the bulldozer had been highjacked by CB settlers. After being accused of being an OFP spy, my colleagues and I were invited to leave and we promptly walked back to Rincon in two day. OFP never used the road to control settlers in CB and after two years of abandonment, the ill-fated road disappeared

By 1973, a committee within the Costa Rican national legislature recommended expropriating most of OFPs land; part would be for a national park and the rest would be given to settlers. The reserve creation was influenced by scientists and not by local residents. Actually, the TSC provided the reserve design without OFP being aware. Hostility between OFP and locals continued and in late 1973, an OFP guard was killed. Then in early 1974, the OFP manager left Costa Rica, stealing the down payments for a home site and resort development project. OFP was forced to quickly plan for massive and intensive development of their holdings, partly to avoid more land being usurped by settlers and also to stave off more criticism by the Costa Rican government.

Their new plans included cattle ranching (2 100ha), mechanized agriculture (1 200ha), tourism and logging. The logging operations were to be contracted to a major Japanese firm, Mitsui, which would clear-cut 33 500ha for pulpwood at the rate of 3 000ha a year. These areas were to be replanted with a variety of exotic forest species (Pinus caribea, Eucalyptus deglupta, Gmelina arborea) (Sandwell 1974). Two thousand hectares would be set aside on the Golfo Dulce side for campesino settlements and almost 10 000ha for watershed management in the mountainous area above Rincon, Riyitos and Vaquedano. A large-scale tourist project for foreigners in the Rincon area planned to sell about $25 \%$ of their lands in 1830 lots. Another resort project, which sounded the alarm for conservationists, was to dredge part of the $C B$ and install a large marina. The forestry and resort projects, projected to produce about US\$10 000000 in profits for OFP were widely publicized. However, because of major and unrelated efforts by conservationists and the Costa Rican government stakeholders, none materialized.

\section{Conservationists infiltrate the OP and sound the alarm}

The third and fourth group of stakeholders was the international conservation donors and foreign scientists (Table 1). In general, the donors offered moral and then financial support to the scientists and then the Costa Rican government and CRNPD. Concurrent to the deteriorating OFP situation on the OP, a movement was unfolding to conserve part of the OP for posterity as a national park. Curiously, this movement was promoted right under the nose of OFP, who were directly affected. Here is how it occurred. The main offices in San Jose of OFP and the TSC, a scientific consulting organization, were found in close proximity. In 1962, the OFP manager invited the TSC to construct a research station in isolated Agua Buena de Rincon. This site was on OFP property about two kilometers above Rincon. Between 1962-73, over a thousand scientists, biology students and researchers visited the station and conducted research. Most were members of the Organization for Tropical Studies (OTS), a scientific research and education consortium of United States and Latin American universities (Vaughan 1981).

The TSC facility served as a take-off site for scientists who wanted to explore the OP. A few made the two-day trek to the $C B$, returning with incredible stories about the amazing forests and wildlife. The scientists tried to keep a separate identity from OFP, but the local community identified them as OFP supporters, which OFP endorsed. Finally in 1973, OFP shut down the TSC station, probably due to the campaign that TSC and OTS scientists were carrying out to create CNP on OFP land in the CB.

This was not before foreign scientists had begun working on the CNP idea. In 1969, several OTS scientists who had worked on the OP, Jack Ewel and Douglas Pool (University of Florida) and Monty Lloyd (University of Chicago), spearheaded a drive to conserve part of the OP. Contact was made initially with The Nature Conservancy. Ewel and Pool published a booklet in 1973 entitled The Corcovado Basin describing the CB and proposing it as CNP. This document helped unite conservationists to the idea that any protected area in the OP should include the CB and be run by Costa Rica (Christen 1994).

The TSC was a major stakeholder within the scientific conservation group that created CNP. They leased the research station at Rincon, thus allowing scientists to work in the region. Also, in the early 1970's the TSC was conducting a survey of potential Costa Rican national parks and protected areas funded by the World Wildlife Fund-US (Tosi et al. 1973). Team members were: Leslie Holdridge (dendrologist), Joseph Tosi (geographer and coordinator), Alexander Skutch (ornithologist), Olaf Wessburg (mammalogist) and myself. Unfortunately, Olaf Wessburg was killed in the CB just weeks before I entered there the second time. Of the team, I was the only person who traveled and remained in the potential national park sites for extended periods. The other team members had visited many sites some years before or worked off of maps and photographs. When we started the survey in mid-1971, Costa Rica had only four national parks (Volcan Irazu, Volcan Poas, Cahuita and Santa Rosa) for a total of 18 100ha. Based largely on the TSC recommendations, the Costa Rican government added 17 
more national parks and equivalent reserves for a total of about 175 000ha by 1978. In addition, Joseph Tosi's report on potential land use in the OP was used by the Costa Rican Congress to propose expropriation of OFP land and creation of CNP (Tosi 1971). Tosi, myself and TSC and OTS were definitely wolves in sheep's clothing concerning our use of OFP property.

However, infighting began between the conservation camps (OTS, TSC, CRNPD ) over who would develop and control a scientific station in the eventuality of creating CNP. It was a ludicrous scenario for me, because we weren't even sure that there would be a CNP. Increasing numbers of settlers in $C B$, conservationists bickering and OFP with their grandiose plans for CB made it difficult to predict. Finally, conservationists united when OFP stepped up ideas of developing Rincon Resorts in the CB. Their plans included: (a) constructing a major road to the $C B$, (b) dredging the CB lagoon to connect to the Pacific Ocean, (c) building an inland marina, and (d) constructing 2000 home sites (Christen 1994).

On the surface, my job as a CRNPD and TSC biologist was to conduct rapid ecological surveys on the CB's biological importance, focusing on large mammal populations. A second role was to determine potential borders for this incredibly diverse wild land area, based on maps, aerial photographs and especially ground surveys. However, a major role a local two locals and I played in creation of CNP was to infiltrate the CB area and collect information about the approximately 98 families of settlers living there. Our mission was to learn about their leaders, their nationalities, their permanency in Corcovado, sites of farms, agricultural crops, land uses, agricultural dependency, trade routes, plans, political parties supporting them, and strength of their opposition (Vaughan 1981). This I reported this to Mario Boza, head of the CRNPD and Joseph Tosi, coordinator of the TSC project. It was exciting, but reflecting back on it, it was dangerous and I was over my head from the beginning. My main colleagues and informants were two local residents, Feyner Salazar, son of a swine herder on Llorona beach and Rafael Rubi, a goldminer from the Claro river. I still don't understand all their conservation motives. However without both of them, I am convinced that CNP would not exist today. I especially remember Feyner's treks over the mountains to Pto. Jimenez to inform Mario Boza and I about the plans of the settlers in the CB.

\section{Three governmental actors with very different agendas?}

The Costa Rican Congress, President Oduber and the CRNPD are the last stakeholders in our story. They each played a major role in the creation of CNP, even if it wasn't their major agenda (Table 1). Members of the Costa Rican Congress had been interested in expropriating OFP for several years, motivated by accusations of land-hoarding and tax evasion more then a conservation policy. The fact that they would so strongly approved (45-4) OFPs expropriation indicated that even members of Oduber's Liberation Party wanted the President to move forward on expropriation. President Oduber was not interested in expropriating the OFP and after vetoing the law sent by Congress, explored options less tarnishing to his name or party. He was a very large land owner in the Northwest part of Costa Rica.

The CRNPD was a very young organization created as a division of the Forestry Service in 1970. Its charismatic and ambitious leader, Mario Boza, was steeped in national parks philosophy by his years as a M.Sc. student of Kenton Miller at the Interamerican Institute of Agricultural Sciences (Turrialba, Costa Rica). His thesis was a management plan for Poas National Park, the first national park created in Costa Rica. Mario's right hand man was Alvaro Ugalde, first director of Santa Rosa National Park who replaced Mario as Director of CRNPD in the late 1970s. Together, they built up a world renowned system in only a decade. Mario was a very creative thinker living on a shoestring budget for his parks. For instance, although his total professional staff consisted of four Costa Ricans in 1971, he more then doubled it by bringing in five Peace Corps Volunteers. In eight years as director of the CRNPD (19701978), Mario and his staff created and began to manage a total of 11 national parks, one national monument and six biological reserves, totaling over 175,000 hectares. In the case of CNP, Mario and Alvaro (close personal friend of Daniel Oduber) were totally dedicated to its creation and worked very hard to get it approved. Both were excellent politicians with congress and conservation organizations.

\section{The tip of the iceberg with OFP precipitates creation of Corcovado National Park}

\section{Expropriation of OFP}

The Costa Rican government wasn't normally engaged in land expropriations. However, they had taken Anastasia Somoza's (Nicaraguan dictator) hacienda in 1971, making Santa Rosa National Park, so there was a precedent. However, after an exhaustive analysis, the congressional committee concluded that OFP was a typical case of land hoarding and tax evasion and recommended immediate expropriation of its lands, except those dedicated to tourist development. The congressmen drafted a law for the expropriation, which included a chapter on potential land use on the OP. The law also included recommendations 
for granting settlers their agricultural and forestry lands (Costa Rica, Asamblea Legislativa 1973). Finally, the report recommended the creation of CNP in the $C B$, similar to what occurred in Santa Rosa National Park. TSC provided the congressmen with the potential land map use of the OP, including the limits and text for creating CNP, which I had drawn up.

The proposed legislation to expropriate OFP was discussed in Congress without arriving at a definitive decision. Finally on August 30, 1975, the proposed law was approved by a vote of 45 in favor and four against. However, when it arrived at President Oduber's desk for his signature to make it official, he vetoed it. He reasoned that it was unconstitutional to expropriate land and he would not condone taking away foreigners properties during his administration. At that moment, it seemed doubtful that the Costa Rican Congress would override Oduber's veto. However, it OFP remained with its lands, the entire $C B$ and its other forested properties were in jeopardy by settlers or OFPs marina or forestry projects. It looked like a lose-lose situation. Feyner, Rubi and I were aware that unless CNP was declared before January, 1976 when the three month dry season began, extensive burning and deforestation would occur, seriously threatening the integrity of CNP. Additional settlers and speculators were arriving every month and planned to carve out parts of the $\mathrm{CB}$ when the rains ceased. I remember writing a report to Mario Boza and Joe Tosi, stating that "There was not one square meter in the $C B$ or in the nearby hills that was not marked with boundary lines and claimed by an owner" (Vaughan 1981). I urged them to remedy the situation.

\section{The land swap and creation of CNP}

Still concerned about a possible expropriation of OFP and probably influenced by Alvaro Ugalde, in September of 1975, President Oduber began negotiations with OFP to exchange lands controlled by the Costa Rican government and OFP on the OP. Specifically the Costa Rican government wanted OFP lands in the CB for CNP. OFP wanted public lands located in the center of the Osa Peninsula which emptied into the Golfo Dulce and a terrestrial exit to the Sierpe river. After extensive negotiation, an agreement was reached for a land exchange (Fig. 3). The agreement took the form of Executive Decree \#5343-A signed by President Oduber on October 24, 1975. OFP received 13,751 hectares in the center of the OP and 1413 ha to the Sierpe river (Fig. 1)(Vaughan 1981). Many people thought Oduber wanted the land exchange to repel congress overriding his veto. Others felt he gave OFP the lands with fewest settlers in exchange for the very conflictive $C B$. Executive Decree \#5357-A creating CNP was signed the same day. In addition to clarifying the limits of the park, the decree also listed prohibitions and named a scientific advisory committee to advise the CRNPD in its management. The committee was charged with writing a law for the park to give it more legal support and importance.

\section{Emergency committee}

Once CNP was created, the 250+ residents had to be moved. Many families were promised new plots of land outside the park if they had been CB residents for over three years. All residents had to be compensated for the "improvements" (land cleared, crops, pastures, building, fruit trees, etc.) they made of OFP land. Some, who had lived in the zone for over 20 years (case of Francisco Marenco) weren't interested in moving. Although, their presence was a menace to CNPs natural resources, CNP legislation did not include provisions for organizing or financing these actions. It appeared that the Costa Rican government would inherit the OFP problem. Was this planned, I remember thinking?

However, on January 26, 1976, in a surprise move, Oduber declared CNP a national emergency "disaster zone". This provided emergency funds normally assigned for catastrophe relief (hurricanes, floods, epidemics) to deal with the settlers in CNP and its protection and management. Funds were needed to: (a) maintain settlers until their lands could be assessed, (b) assess their "improvements" (deforestation, constructions, crops- bananas, corn, beans, fruit trees, pasture, etc., fences, etc.), (c) pay them for their "improvements", (d) provide land and/or money to residents who had farmed in the CB region over 3 years ("possession rights"), (e) pay off outstanding bank loans, (f) move all $250+$ residents, and (g) protect and manage CNP. This trump card by Oduber got the ball rolling.

Land tenure studies were quickly carried out by inspectors from the Institute for Lands and Colonization (ITCO). However, after several days of visiting farms and carefully documenting crops, size of cultivated areas, state of constructions, etc, the inspectors tired. In the end, settlers "reported" what their farms contained, while the inspectors sat at a table in a central area. Reading their reports, one can only question how hectares of cabbage, cacao, and coffee appeared suddenly in the CB when none had existed previously (Costa Rica. Instituto de Tierras y Colonizacion 1975a, 1975b, 1975c). Total payments for all families amounted to about US\$1 000000 , probably $25 \%$ more then would have occurred with careful land tenure inspections. The national emergency act, donations from World Wildlife Fund and The Nature Conservancy and emission of agricultural bonds from the Central Bank of Costa Rica paid this. There was additional money available in Costa Rica in 1975, due 
to record prices in the coffee crop (coffee" bonanza"), product of killing frosts which had destroyed most of Brazil's coffee crop. Many people left CNP after receiving their check. Although it took several months of negotiation before the settlers' leaders and government signed a letter of cooperation in the Presidential House on May, 1976.

\section{DISCUSSION}

When Executive Decree \#5343-A creating Corcovado National Park (CNP) was signed on October 24, 1975, a new set of rules began for this neotropical region. How did the stakeholders fare? Can lessons for current conservation practices of CNP and the OP be learned for the OP and other conservation efforts in developing countries?

\section{Settlers and goldminers of the Corcovado Basin}

There was no doubt that the CB inhabitants had modified their environment. Deforestation of an estimated 1 800 ha had occurred. Also populations of many wildlife species were scare throughout most of the CB. The impacts of their domestic pigs on the soil microfauna and understory were probably great as has been documented on Hawaii, Great Smoky Mountain National Park and elsewhere. Selected hardwoods had been felled for constructions, furniture and to plant crops, affecting the genetic stock in the CB. Population had quadrupled in only two years time. Thus the impacts caused by the settlers would have been severe if they had remained longer in the CB.

How did the $240+$ residents fare after CNP was created? This was one of Costa Rica's most isolated agricultural settlements in the 1970s and remains today an extremely difficult protected area to visit. Agricultural crops were grown without chemical fertilizers, wild animals would damage your crops and kill your livestock. Houses were very rustic and in most areas, you were almost surrounded by the jungle. There were no doctors nor health facilities, no roads nor motorized vehicles, two school teacher and schools at opposite ends of the $C B$, but hours away from most students, and only one general store. Most settlers had been in the CB less then 3 years, but some had lived there over 20 years. Transportation was extremely difficult. Agricultural crops were grown without chemical fertilizers, wild animals would damage your crops and kill your livestock. Houses were very rustic and in most areas, you lived surrounded by the jungle. Golminers were hardly affected by the creation of CNP because they lived in very isolated areas and except for some hunting, kept to themselves.

Most settlers in the $C B$ were satisfied to move to a more accessible site with roads, health facilities, schools and relatives. Many settled on the Golfo Dulce side of the OP at the ITCO colonies of Canada or La Palma; others wasted the money given to them and were broke after several months. Those who had bank loans for developing a cattle herd were satisfied when their bank credits were paid. Also most settlers were given much more in terms of land and money because they didn't tell the inspectors the truth.

\section{Osa Forest Products}

The transnational OFP, owner of almost 60 000ha of mostly forested lands on the OP did very well in the land swap. Accused of tax evasion, human rights abuser, and usurper of tens of thousands of hectares on the OP, it was granted a temporary stay. Simultaneous creation of CNP and a massive land exchange between the Costa Rican government and OFP couldn't have been better timed. OFP had been given pristine, uninhabited lands in the heart of the Peninsula in exchange for a CB filled with squatters and international conservationists clamoring for a national park. Now it was the Costa Rican governments' problem to rid CNP of squatters. What more could OFP expect? When Oduber received an international conservation award from the New York Botanical Garden for creation of CNP, many asked why.

\section{International conservation community}

The international conservation community (donors and scientists) was very content for the time and money they had invested. They pledged to continue support for the management of CNP. The financial burden was to be assumed by the international conservation organizations, such as The Nature Conservancy and the World Wildlife Fund-US. The TSC has not been active in the OP since they abandoned their research station and finished the report on potential national parks. However many OTS related scientists wanted to access this biological storehouse of CNP for scientific pursuits. The general store in Sirena became the administration center for the park and research center for scientists, students and ecotourists, the bulk of the visitors.

Dr. Larry Gilbert of the University of Texas pioneered research efforts and built a scientific research station in Sirena in the early 1980s with an NSF grant. Up to the present day, he has maintained this site as his main research site and spends several months a year there, giving courses and conducting research. Additionally, probably a dozen of his graduate students have carried out their thesis or dissertation research there. 
Since the late 1970s, the Organization for Tropical Studies (OTS) has also regularly spent time at Sirena. OTS brings graduate (and now undergraduate) students and staff from their tropical biology courses. Over 30 students and professors from several courses hike in and stay at Sirena, conducting short-term research project for over a week. OTS probably invests several 1000 researcher days a year in CNP. Some of these graduate students or their professors return to conduct research, oftentimes for thesis or dissertation afterwards. Graduate students associated with my Costa Rican university (Universidad Nacional) have been conducting research on large mammals (tapirs, peccaries, jaguars) in CNP for over a decade (Alger et al. 1998, Forester \& Vaughan 2002, Altrichter et al. 2001)

Ecotourists provide about 1500 visitor days to CNP. Most ecotourists don't rough the primitive conditions at Sirena, and overnight outside of the park at resorts (Lapas Rios, Corcovado Lodge, Marenco to name a few). These sprung up in response to a demand for facilities. Visitors from these resorts oftentimes travel to the Sirena area of CNP by boat and spend the day or enter parts of the park closer to their resort.

\section{The Costa Rican Government}

The Costa Rican Congress was instrumental in creating CNP. However they were not able to censure the OFP and expropriate their lands. In fact after the land swap, OFP retained a similar amount of land which was in a pristine condition. However it was more difficult to exploit and eventually OFP left the OP without realizing its grandiose plans.

President Oduber was probably much relieved after masterminding the land swap. He avoided having his veto overridden, he kept his word about avoiding expropriation of foreigner's lands and made an ally in OFP. If he championed the emergency proposal and bank bonds for CNP, he (or Alvaro Ugalde) deserved the conservation award he was given several years later by the New York Botanical Society for creation of CNP.

The CRNPD (now National System of Conservation Areas-SINAC) and ultimately the Costa Rican government won the jackpot. They received the "gem" of biodiversity of their system. Today it is still lauded as one of the most diverse ecological systems for its size on earth. CNP has caused major headaches to its caretakers because it is so exposed to settlement, lumber interests, hunting and goldmining from the opposite side of the OP.

\section{An Analysis of Stakeholder Interactions}

CNP has gone through at least four phases in its 25 year history. This includes: (a) establishment, (b) community involvement, (c) integrated conservation-development project, and most recently, (d) regional planning (Cuello et al. 1998). At present, logging, unsustainable agricultural activities, and development threaten most of the OP and professionals call for improved organization and implementation of conservation efforts. A major campaign is developing involving a dozen national and international organizations and several million dollar support (Neotropical Foundation 2000). Perhaps present approaches to conservation can benefit from the historical perspective and analysis presented below. Is there anything in its historical and tumultuous creation which can lead us to solve the many problems it faces today? We believe that open communication and searching for win-win situations fomented the creation of Corcovado National Park.

\section{ACKNOWLEDGEMENTS}

I wrote this while on a sabbatical from the Universidad Nacional at the University of Wisconsin-Madison where I was named honorary fellow within the Nelson Institute of Environmental Studies. Drs. Thomas Yuill, Raymond Guries and Scott Craven were of great assistance. While in the Osa Peninsula in the 1970's, Feynor Salazar and Rafael Rubi was great friends and companions. The scarlet macaws, tapirs, jaguars, kinkajous and all other biodiversity species were great stimulators for me to try to preserve and manage wildlands and its biodiversity in Latin America.

\section{REFERENCES}

Alger, S., C. Vaughan, \& C. Foerster. 1998. Resting site microhabitat selection by Tapirus bairdii during the dry season in Corcovado National Park, Costa Rica. Vida Silvestre Neotropical 7:136-138.

Altrichter, M., J. Saenz \& E. Carrillo. 2001. Prespuesto de tiempo del chancho de monte (Tayassu pecari) en un bosque húmedo de Costa Rica. Biotropica 34:136-143.

Batisse, M. 1986. Developing and focusing the biosphere reserve concept. Nature and Resources 22:1-22.

Boza, M. \& A. Bonilla. 1981. The national parks of Costa Rica. INCAFO, Madrid, Spain

Brandon, K., K. Redford, \& S. Sanderson. 1998. Parks in peril: People, politics and protected areas. Island, Washington, D.C., USA.

Brandon, K. \& M. Wells. 1992. Planning for people and parks: Design dilemmas. World Development 20:557-570. 
Carranza, M. 1982. La loca de Gandoca. Lehmann, San Jose, Costa Rica.

Christen, C. 1994. Development and conservation on Costa Rica's Osa Peninsula, 1937-1977: A regional case study of historical land use policy and practice in a small neotropical country. Ph.D. dissertation, Johns Hopkins University, Baltimore, MD, USA.

Compañía Bananera de Costa Rica. 1945. Analisis de los suelos del distrito de Salsipuedes, Golfito, Costa Rica.

Costa Rica. Asamblea Legislativa. 1973. Denuncias contra la Osa Productos Forestales. Asamblea Legislativa. San Jose, Costa Rica.

Costa Rica. Banco Anglo Costarricense. 1976. Datos sobre la zona de San Pedrillo, río Corcovado, etc. Informe. San Jose, Costa Rica.

Costa Rica. Dirección General de Estadística y Censos. 1973. Censos nacionales de 1973. Agropecuario. Direccion General de Estadistica y Censos. San Jose, Costa Rica.

Costa Rica. Instituto de Tierras y Colonizacion. 1975a. Estado de tenencia de la tierra y censo de ocupantes y actos de explotacion en la Osa Productos Forestales en lotes 10, 11, 12 , y 13 segun plan aportado por dicha compania. San Jose, Costa Rica.

Costa Rica. Instituto de Tierras y Colonizacion. 1975b. Estado de tenencia de la tierra y censo de ocupantes en la Osa Productos Forestales. 1 etapa. San José, Costa Rica.

Costa Rica. Instituto de Tierras y Colonizacion. 1975c. Estado de tenencia de la tierra y censo de ocupantes y actos de explotacion en la Osa Productos Forestales en lotes 3, 4 y partes 5 y 6 . San Jose, Costa Rica.

Costa Rica. Ministerio de Salud. 1975. Plan de trabajo para inspeccion de evaluacion epidemiologica de malaria. San Jose, Costa Rica.

Cuello, C. 1997. Sustainable development in theory and practice: A Costa Rican case study. Ph.D. dissertation. University of Delaware, Newark, Delaware, USA.

Cuello, C., K. Brandon, \& R. Margoluis. 1998. Costa Rica: Corcovado National Park. 143-191. In Brandon, K., Redford, K. \& S. Sanderson (eds). Parks in peril: People, politics and protected areas. Island, Washington, D.C, USA.

Foerster, C. \& C. Vaughan. 2002. Home range, habitat use and activity of Baird's tapir in Costa Rica. Biotropica 34:423-437.

Hales, D. 1989. Changing concepts of national parks. In Western, D. \& M. Pearl (eds).. Conservation in the twenty-first century.. Oxford University, New York, NY, USA

Hartshorn, G. 1983. Plants. 118-350. In Janzen, D. (ed.).Costa Rican natural history. University of Chicago, Chicago, USA.

International Union for Conservation of Nature and Natural Resources (IUCN). 1980. World Conservation Strategy: Living resource conservation for sustainable development.: IUCN, Gland, Switzerland.
Kramer, R. \& C. VanSchaik. 1997. Preservation paradigms and tropical rain forests. 3-10. In Kramer, R., VanSchaik, C. \& J. Johnson (eds.).Last stand: Protected areas and the defense of tropical biodiversity. Oxford University, New York, NY, USA.

Ledec, G. \& R. Goodland. 1988. Wildlands: Their protection and management in economic development. The World Bank, Washington, D.C., USA.

McNeely, J. \& K. Miller. 1984. National Parks, conservation and development: The role of protected areas in sustaining society. Smithsonian Institution, Washington, D.C., USA.

Naughton, L. 1993. Conservation versus artisan gold mining in Corcovado National Park, Costa Rica: Land use conflicts at neotropical wilderness frontiers. Yearbook, Conference of Latin American Geographers. 19:47-55.

Neotropical Foundation. 2000. The Osa biological corridor: Phase I. Draft project proposal.

Rao, K. \& C. Geisler. 1990. The social consequences of protected areas development for resident populations. Society and Natural Resources 3:19-27

Redford, K., K. Brandon, \& S. Sanderson. 1998. Holding ground. In Brandon, K., Redford, K. \& S. Sanderson (eds). Parks in peril: People, politics and protected areas. Island, Washington, D.C., USA.

Reid, W. \& K. Miller. 1989. Keeping options alive: The scientific basis for conserving biodiversity. World Resources Institute, Washington, D.C., USA.

Rossi, A. 1993. La loca de Gandoca, EDUCA., San José, Costa Rica. 140p.

Sandwell, Inc. 1974. Costa Rica wood chip project feasibility study. Vancouver, Canada.

Sellars, R. 1997. Preserving nature in the national parks. Yale University, New Haven, USA.

Soto, R. 1992. Evaluacion ecologica rapida, Peninsula de Osa. San Jose, Costa Rica: Fundacion Neotropica. San Jose, Costa Rica.

Terborgh, J. 1999. Requiem for nature. Island, Washington, D.C., USA.

Tosi, J. 1971. Mapa de uso potencial de la tierra de la Peninsula de Osa. Centro Cientifico Tropical.San Jose, Costa Rica.

Tosi, J., L. Holdridge, A. Skutch \& O. Wessburg. 1973. Areas potenciales de parques nacionales, reservas naturales y santuarios de la vida silvestre de Costa Rica: Un estudio de prioridades. Centro Cientifico Tropical, San Jose, Costa Rica.

Tucker, R. 1990. Five hundred years of tropical forest exploitation. 39-52 p. In Head, S. \& R. Heintzman (eds.). Lessons from the Rain Forest, Sierra Club Books, San Francisco, USA.

VanSchaik, C., J. Terborgh, \& B. Dugelby. 1997. The silent crisis: The state of rain forest nature preserves. 64-89 p.. In Kramer, R., VanSchaik, C. \& J. Johnson (eds.). Last stand: 
Protected areas and the defense of tropical biodiversity, Oxford University. New York, NY, USA.

Vaughan, C. 1974. Endangered wildlife species: The spotted cats. Agropecuaria 4:15-19.

Vaughan, C. 1981. Parque Nacional Corcovado: Plan de manejo y desarrollo. Universidad Nacional, Heredia, Costa Rica.

Vaughan, C. \& C. Rodriguez. 1997. Managing beyond borders:The Costa Rican National System of Conservation Areas (SINAC). 441-451 p. In Meffe, G. \& R. Carroll (eds.). Principles of Conservation Biology. Sinauer, Sunderland, MA, USA.

Wells, M. 1994. Biodiversity conservation and local development aspirations: New priorities for the 1990s. 306-320p. In Perrings, C,.Maler, K. \& C. Holling (eds.), Biodiversity Conservation: Problems and policies. Kluwer, Amsterdam.
Wells, M. \& K. Brandon. 1992. People and parks: Linking protected area management with local communities. The World Bank. Washington, D.C., USA.

Whitmore, T. \& J. Sayer. 1992. Tropical deforestation and species extinction. Chapman and Hall.,London, England.

Wilson, E. 1989. Biodiversity. National Academy, Washington, D.C., USA.

World Conservation Monitoring Center. 1992. Global biodiversity: Status of the Earth's living resources. Chapman and Hall, London, England.

Worldwatch Institute. 1999. State of the World. Norton, New York, NY, USA. 